\title{
Tenacibaculum discolor sp. nov. and Tenacibaculum gallaicum sp. nov., isolated from sole (Solea senegalensis) and turbot (Psetta maxima) culture systems
}

\author{
Maximino Piñeiro-Vidal, ${ }^{1}$ Ana Riaza ${ }^{2}$ and Ysabel Santos $^{1}$ \\ ${ }^{1}$ Departamento de Microbiología y Parasitología, Facultad de Biología, Universidad de Santiago de \\ Compostela, Campus Sur 15782, Santiago de Compostela, Spain \\ ${ }^{2}$ Stoltseafarm S.A., Lira, Spain
}

Correspondence

Ysabel Santos

ysantos@usc.es

Two Gram-negative, rod-shaped, gliding bacterial strains, designated strain LL04 $11.1 .1^{\top}$ and strain $A 37.1^{\top}$, were isolated from a diseased sole (Solea senegalensis) and from seawater from a holding tank for turbot (Psetta maxima), respectively. The strains grew on solid media as bright yellow colonies with uneven edges; the colonies did not adhere to the agar. The bacteria were able to grow at temperatures in the range 14 to $38^{\circ} \mathrm{C}$ and from $\mathrm{pH} 6.0$ to $\mathrm{pH}$ 8.0. The DNA $\mathrm{G}+\mathrm{C}$ contents of strains LLO4 $11.1 .1^{\top}$ and $A 37.1^{\top}$ were 32.1 and $32.7 \mathrm{~mol} \%$, respectively. Analysis of the 16S rRNA gene sequences indicated that strains LL04 11.1.1 ${ }^{\top}$ and $A 37.1^{\top}$ were members of the genus Tenacibaculum in the family Flavobacteriaceae. The sequence similarities of the two isolates with respect to the type strains of recognized members of the genus ranged from 94.2 to $99.4 \%$. DNA-DNA hybridization studies revealed that the strains studied represent two distinct novel species of the genus Tenacibaculum, for which the names Tenacibaculum discolor sp. nov. [type strain LL04 11.1.1 ${ }^{\top}\left(=\operatorname{NCIMB} 14278^{\top}=\mathrm{DSM} 18842^{\top}\right)$ ] and Tenacibaculum gallaicum sp. nov. [type strain $A 37.1^{\top}\left(=\operatorname{NCIMB} 14147^{\top}=\mathrm{DSM} 18841^{\top}\right)$ ] are proposed.

The genus Tenacibaculum, proposed by Suzuki et al. (2001), belongs to the family Flavobacteriaceae (Reichenbach, 1992a, b; Bernardet et al., 1996, 2002) and currently comprises nine species: Tenacibaculum maritimum from diseased fish (Wakabayashi et al., 1986), T. ovolyticum from fish eggs (Hansen et al., 1992), $T$. amylolyticum from the surfaces of marine macroalgae and T. mesophilum from sponges (Suzuki et al., 2001), T. skagerrakense isolated from seawater (Frette et al., 2004), T. lutimaris, T. litoreum, T. aestuarii from tidal flat sediment (Yoon et al., 2005; Choi et al., 2006; Jung et al., 2006) and $T$. litopenaei isolated from a shrimp mariculture pond (Sheu et al., 2007).

During the characterization of bacteria isolated from the kidney of a diseased sole (Solea senegalensis) and from seawater from holding tanks for turbot (Psetta maxima), strains LL04 11.1.1 ${ }^{\mathrm{T}}$ and A37.1 ${ }^{\mathrm{T}}$ were recovered on plates of Flexibacter maritimus medium (FMM; Pazos et al., 1996) at $25{ }^{\circ} \mathrm{C}$ (T. maritimum was previously misclassified within the genus Flexibacter). The diseased fish showed the typical

The GenBank/EMBL/DDBJ accession numbers for the 16S rRNA gene sequences of strains LL04 $11.1 .1^{\top}$ and $A 37.1^{\top}$ are AM411030 and AM746477, respectively. signs observed in fish affected by marine flexibacteriosis caused by T. maritimum (i.e. eroded mouth, rotten fins, shallow skin lesions and paleness of internal organs). Pathogenicity assays demonstrated that the isolated bacteria were virulent for turbot and sole (Piñeiro-Vidal et al., 2007). The isolated bacteria were subcultured on FMM agar at $25{ }^{\circ} \mathrm{C}$ for $48 \mathrm{~h}$ and maintained at $-80{ }^{\circ} \mathrm{C}$ both in FMM broth supplemented with $15 \%$ (v/v) glycerol and in Microbank tubes (Prolab Diagnostics).

Morphological, physiological and biochemical tests were performed as described by Bernardet et al. (2002). The Gram reaction was tested by using the bioMérieux Gramstain kit (according to the manufacturer's instructions) and the non-staining KOH method (Buck, 1982). Gliding motility was determined by phase-contrast microscopic examination of a fresh FMM broth culture and by the hanging drop technique as recommended by Bernardet et al. (2002). The presence of flexirubin-type pigments was determined by using the $\mathrm{KOH}$ test as described by Reichenbach (1989). Catalase and oxidase activities were determined as described by Cowan \& Steel (1965). The ability of the strains to grow under anaerobic conditions was tested in FMM agar by using the GasPak anaerobic system (BBL). To assess their growth at different $\mathrm{pH}$ values, 
the strains were cultured in FMM broth adjusted to $\mathrm{pH}$ values ranging from 4 to 10 . The temperature range for growth was determined on FMM agar plates incubated at $8,15,18,22,25,30,37$ and $44{ }^{\circ} \mathrm{C}$. Tolerance of salinity was tested in FMM broth containing seawater strengths of 10 , $20,30,50,70$ and $100 \%$ or at $\mathrm{NaCl}$ concentrations of 0.8 , $1,3,5,7$ and $10 \%(\mathrm{w} / \mathrm{v})$. Indole production was tested in FMM broth supplemented with $1 \%(\mathrm{w} / \mathrm{v})$ tryptone, $\mathrm{H}_{2} \mathrm{~S}$ production was determined in FMM broth supplemented with $5 \%(\mathrm{w} / \mathrm{v})$ peptone and the Voges-Proskauer reaction was determined in seawater supplemented with $0.7 \%(\mathrm{w} / \mathrm{v})$ peptone and $0.5 \%(\mathrm{w} / \mathrm{v}) \mathrm{D}$-glucose. The ability of the novel strains to degrade casein (1\%), gelatin (1\%), starch $(0.4 \%)$ and Tween $80(1 \%)$ and to produce nitrate reductase were evaluated in FMM medium supplemented with substrate concentrations as reported previously (Suzuki et al., 2001). The utilization of carbon sources was tested on basal agar medium [containing, $1^{-1}$ artificial seawater (Sigma), $0.2 \mathrm{~g} \mathrm{NaNO}_{3}, 0.2 \mathrm{~g} \mathrm{NH}_{4} \mathrm{Cl}, 0.05$ g yeast extract, $15 \mathrm{~g}$ agar] supplemented with $0.4 \%$ carbon source [(+)-D-sucrose, (-)-D-ribose, (+)-D-galactose, (+)-Dglucose, L-proline, L-glutamate or L-tyrosine] as described by Suzuki et al. (2001). The absence of growth after incubation in the media for 1 month was scored as a negative result. Other enzymic activities were evaluated using the API ZYM system (bioMérieux) according to the manufacturer's instructions, except that sterile seawater was used as the suspension medium.

The results of the morphological, physiological and biochemical tests are given in the species descriptions and in Table 1.

Sequencing of the 16S rRNA gene of the isolates was carried out by the Identification Service of the Coleccion Española de Cultivos Tipo (Universidad de Valencia, Valencia, Spain). The resulting sequences of strains LL04 $11.1 .1^{\mathrm{T}}(1512 \mathrm{bp})$ and $\mathrm{A} 37.1^{\mathrm{T}}(1518 \mathrm{bp})$ were aligned automatically (using CLUSTAL w; Thompson et al., 1994) with those of the type strains of the nine species of the genus Tenacibaculum and other representative members of the family Flavobacteriaceae obtained from GenBank. The $16 \mathrm{~S}$ rRNA gene sequence similarities were determined using MEGA, version 3.1 (Kumar et al., 2004). Phylogenetic trees were constructed by using the neighbour-joining (Saitou \& Nei, 1987) and maximum-parsimony (Fitch, 1971) methods (Fig. 1). The evolutionary distance matrix for the neighbour-joining method was generated according to the Kimura two-parameter model (Kimura, 1980). The robustness of the phylogenetic trees was determined by means of bootstrap analyses based on 1000 replications. In both trees, strains LL04 $11.1 .1^{\mathrm{T}}$ and $\mathrm{A} 37.1^{\mathrm{T}}$ formed a robust cluster with the species of the genus Tenacibaculum. Data from the sequence similarity analysis indicated that the closest relatives of strains LL04 11.1.1 ${ }^{\mathrm{T}}$ and A37.1 ${ }^{\mathrm{T}}$ were T. litoreum ( 99.4 and $98.4 \%$, respectively), T. mesophilum (97.4 and $96.7 \%$, respectively), T. aestuarii ( $97.3 \%$ for both isolates), T. lutimaris (97.3 and $96.8 \%$, respectively), T. skagerrakense (96.4 and $95.9 \%$, respectively), and $T$. amylolyticum and (96.0 and $96.3 \%$, respectively). The $16 \mathrm{~S}$ rRNA gene sequence similarity between strains LL04 11.1.1 $1^{\mathrm{T}}$ and $\mathrm{A} 37.1^{\mathrm{T}}$ was $98.4 \%$.

The DNA G $+\mathrm{C}$ content was determined using the method described by Cashion et al. (1977). As the 16S rRNA gene sequence similarities between strains LL04 $11.1 .1^{\mathrm{T}}$ and $\mathrm{A} 37.1^{\mathrm{T}}$ and between them and the type strain of T. litoreum were close to $99 \%$, DNA-DNA hybridization experiments were performed using the method described by De Ley et al. (1970), as modified by $\mathrm{Huß}$ et al. (1983). The experiment was performed at $45^{\circ} \mathrm{C}$ in $2 \times$ SSC $(1 \times$ SSC is $0.15 \mathrm{M}$ sodium chloride plus $0.015 \mathrm{M}$ sodium citrate at pH 7.0) using a Cary 100 Bio UV/visible spectrophotometer equipped with a Peltier-thermostatted $6 \times 6$ multicell changer and a temperature controller with an in situ temperature probe (Varian). The DNA G $+\mathrm{C}$ content determinations and the DNA-DNA hybridization experiments were performed by the Identification Service of the Deutsche Sammlung von Mikrooganismen und Zellkulturen GmbH (Braunschweig, Germany). The DNA $\mathrm{G}+\mathrm{C}$ contents of strains LL04 11.1.1 ${ }^{\mathrm{T}}$ and A37.1 ${ }^{\mathrm{T}}$ were 32.1 and $32.7 \mathrm{~mol} \%$, respectively (Table 1 ). The DNADNA relatedness between strains LL04 11.1.1 ${ }^{\mathrm{T}}$ and A37.1 ${ }^{\mathrm{T}}$ was $42.8 \%$, and the strains shared 39.6 and $40.2 \%$ relatedness, respectively, with their closest relative, $T$. litoreum. Therefore, we conclude that strains LL04 11.1.1 ${ }^{\mathrm{T}}$ and $\mathrm{A} 37.1^{\mathrm{T}}$ represent two novel bacterial species within the genus Tenacibaculum, for which we propose the names Tenacibaculum discolor sp. nov. and Tenacibaculum gallaicum sp. nov., respectively.

\section{Description of Tenacibaculum discolor sp. nov.}

Tenacibaculum discolor (dis.co'lor. L. neut. adj. discolor of different colours, referring to the colours of the colonies).

Cells are Gram-negative rods that are $0.5 \mu \mathrm{m}$ in diameter, 2-30 $\mu \mathrm{m}$ in length and motile by gliding. Spherical cells are rarely observed in ageing cultures. Colonies on FMM agar medium are flat, bright yellow, have uneven edges and do not adhere to the agar. On marine agar 2216 (Difco), colonies also appear bright yellow from the front, but appear bright green when viewed at an angle of $30-45^{\circ} \mathrm{C}$. The yellow pigment is not of the flexirubin type. Strictly aerobic. Growth occurs in media containing seawater at strengths in the range 30 to $100 \%$ but not in media supplemented with $\mathrm{NaCl}$ alone. Growth occurs at $14-38{ }^{\circ} \mathrm{C}$ (optimum, $25-30{ }^{\circ} \mathrm{C}$ ) and at $\mathrm{pH}$ 6.0-8.0. Catalase and cytochrome oxidase activities are present. Nitrate is reduced. Gelatin and casein are hydrolysed, but Tween 80 and starch are not. The Voges-Proskauer test gives a negative result. No acid is produced from carbohydrates. $\mathrm{H}_{2} \mathrm{~S}$ and indole are not produced. L-Proline and Lglutamate are utilized, but $(+)$-D-sucrose, $(-)$-D-ribose, $(+)$-D-galactose, (+)-D-glucose and L-tyrosine are not utilized. In the API ZYM system, alkaline phosphatase, esterase, esterase lipase, lipase, leucine arylamidase, valine arylamidase, cystine arylamidase, trypsin, $\alpha$-chymotrypsin, 
Table 1. Differential phenotypic characteristics of strains LLO4 $11.1 .1^{\top}$ and A37. ${ }^{\top}$ and the type strains of species of the genus Tenacibaculum

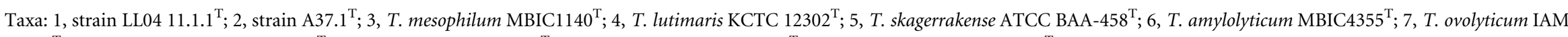

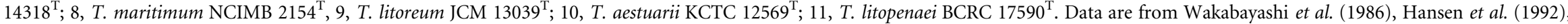

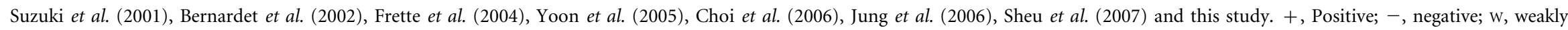
positive; NT, not tested; NG, no growth.

\begin{tabular}{|c|c|c|c|c|c|c|c|c|c|c|c|}
\hline Characteristic & 1 & 2 & 3 & 4 & 5 & 6 & 7 & 8 & 9 & 10 & 11 \\
\hline Origin & $\begin{array}{l}\text { Diseased } \\
\text { sole }\end{array}$ & $\begin{array}{l}\text { Seawater from } \\
\text { holding tanks } \\
\text { for turbot }\end{array}$ & $\begin{array}{l}\text { Sponges, } \\
\text { macroalgae }\end{array}$ & $\begin{array}{l}\text { Tidal flat } \\
\text { sediment }\end{array}$ & Seawater & Macroalgae & Halibut eggs & $\begin{array}{l}\text { Diseased } \\
\text { marine fish }\end{array}$ & $\begin{array}{l}\text { Tidal flat } \\
\text { sediment }\end{array}$ & $\begin{array}{l}\text { Tidal flat } \\
\text { sediment }\end{array}$ & $\begin{array}{l}\text { Shrimp } \\
\text { mariculture } \\
\text { pond }\end{array}$ \\
\hline Cell size $(\mu \mathrm{m})$ & $2-30 \times 0.5$ & $2-30 \times 0.5$ & $1.5-10 \times 0.5$ & $2-10 \times 0.5$ & $2-15 \times 0.5$ & $2-5 \times 0.4$ & $2-20 \times 0.5$ & $2-30 \times 0.5$ & $2-35 \times 0.3-0.5$ & $2.0-3.5 \times 0.3$ & $2-10 \times 0.3-0.5$ \\
\hline Gliding motility & + & + & + & + & - & + & + & + & + & + & + \\
\hline $\begin{array}{l}\mathrm{NaCl} \text { concentration }(\%) \\
\text { for growth }\end{array}$ & NG & NG & $1-7$ & $<8$ & NG & 3 & NG & NG & $3-5$ & $<7$ & $2-10$ \\
\hline $\begin{array}{l}\text { Seawater strength (\%) } \\
\text { for growth }\end{array}$ & $30-100$ & $30-100$ & $10-100$ & $25-175$ & $25-150$ & $50-100$ & $70-100$ & $30-100$ & $25-250$ & NT & NT \\
\hline Temperature range $\left({ }^{\circ} \mathrm{C}\right)$ & $14-38$ & $14-38$ & $15-40$ & $10-39$ & $10-40$ & $20-35$ & $4-25$ & $15-34$ & $5-40$ & $9-41$ & $10-39$ \\
\hline $\begin{array}{l}\text { Optimal } \\
\text { temperature }\left({ }^{\circ} \mathrm{C}\right)\end{array}$ & $25-30$ & $25-30$ & $28-35$ & $30-37$ & $25-37$ & $27-30$ & NT & $25-30$ & $35-40$ & $30-37$ & $28-37$ \\
\hline $\mathrm{pH}$ range & $6.0-8.0$ & $6.0-8.0$ & $5.3-9$ & $7.0-8.0$ & $6.0-9.0$ & $5.3-8.3$ & $5.9-8.6$ & $5.9-8.6$ & $6.0-10.0$ & $5.5-8.5$ & $5-10$ \\
\hline Nitrate reduction & + & + & - & - & + & $\mathrm{W}$ & + & + & + & - & - \\
\hline \multicolumn{12}{|l|}{ Degradation of: } \\
\hline Starch & - & - & - & - & + & + & - & - & + & - & + \\
\hline Gelatin & + & + & + & + & NT & + & + & + & + & + & + \\
\hline Tween 80 & - & - & + & - & - & + & + & + & + & + & - \\
\hline \multicolumn{12}{|l|}{ Carbon utilization: } \\
\hline (+)-D-Sucrose & - & - & - & - & + & - & - & - & - & - & - \\
\hline$(-)$-D-Ribose & - & - & - & NT & NT & - & - & - & - & - & NT \\
\hline (+)-D-Galactose & - & - & NT & NT & NT & NT & NT & - & - & - & - \\
\hline$(+)$-D-Glucose & - & - & NT & - & + & NT & NT & - & - & - & + \\
\hline L-Proline & + & + & + & - & + & + & - & - & + & - & + \\
\hline L-Glutamate & + & + & + & - & + & + & - & $\mathrm{W}$ & - & - & + \\
\hline L-Tyrosine & - & - & NT & NT & NT & NT & NT & - & NT & NT & NT \\
\hline $\begin{array}{l}\text { DNA G + C content } \\
(\mathrm{mol} \%)\end{array}$ & 32.1 & 32.7 & $31.6-32.0$ & $32.3-32.8$ & 35.2 & $31.6-32.0$ & $30.3-32.0$ & $31.3-32.5$ & 30 & 33.6 & 35.2 \\
\hline
\end{tabular}




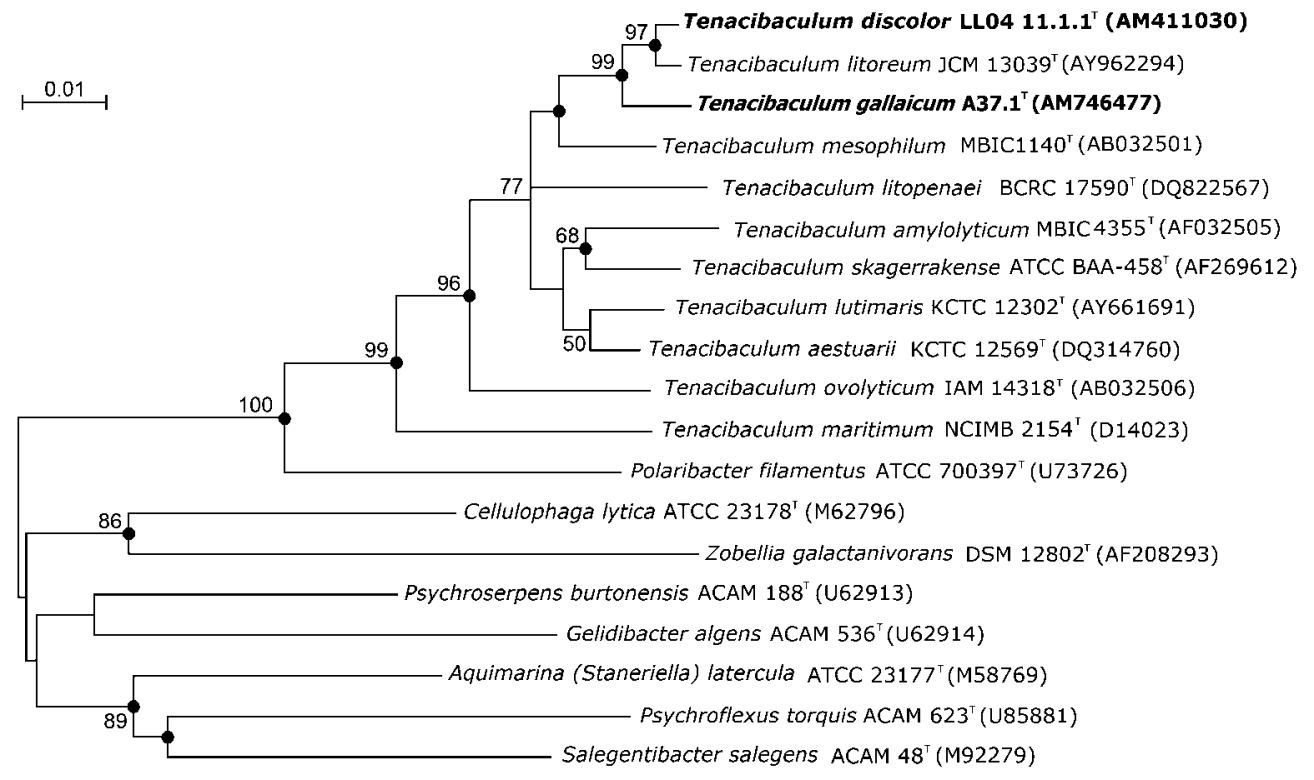

Fig. 1. Neighbour-joining phylogenetic tree, based on $16 \mathrm{~S}$ rRNA gene sequences, showing the relationships between strains LLO4 $11.1 .1^{\top}$ and $A 37.1^{\top}$ and members of the genus Tenacibaculum and other related genera belonging to the family Flavobacteriaceae. Bootstrap percentages (based on 1000 replications) are shown at the branching points. Filled circles indicate that the corresponding nodes were also recovered in the maximum-parsimony tree. Bar, 0.01 nucleotide substitutions per site.

acid phosphatase and naphthol-AS-BI-phosphohydrolase activities are present, but activities for all of the enzymes relating to the metabolism of carbohydrates are absent.

The type strain, LL04 11.1.1 $1^{\mathrm{T}}\left(=\mathrm{NCIMB} 14278^{\mathrm{T}}=\mathrm{DSM}\right.$ $\left.18842^{\mathrm{T}}\right)$, was isolated from the kidney of a diseased sole (Solea senegalensis) in Galicia in north-west Spain.

\section{Description of Tenacibaculum gallaicum sp. nov.}

Tenacibaculum gallaicum (gal.lai'cum. L. neut. adj. gallaicum of Galicia, a north-western province of Spain, referring to the place of isolation).

Cells are Gram-negative rods that are $0.5 \mu \mathrm{m}$ in diameter, $2-30 \mu \mathrm{m}$ in length and motile by gliding. Spherical cells are rarely observed in ageing cultures. Colonies on FMM agar and marine agar 2216 media are flat, bright yellow, have uneven edges and do not adhere to the agar. Strictly aerobic. Growth occurs in media containing seawater strengths of $30-100 \%$, but not in media supplemented with $\mathrm{NaCl}$ alone. Growth occurs at $14-38{ }^{\circ} \mathrm{C}$ (optimum, $25-30{ }^{\circ} \mathrm{C}$ ) and at $\mathrm{pH}$ 6.0-8.0. Catalase and cytochrome oxidase activities are present. Nitrate is reduced. Gelatin and casein are hydrolysed, but Tween 80 and starch are not hydrolysed. The Voges-Proskauer test gives a negative result. No acid is produced from carbohydrates. $\mathrm{H}_{2} \mathrm{~S}$ and indole are not produced. L-Proline and L-glutamate are utilized but $(+)$-D-sucrose, ( -$)$-D-ribose, $(+)$-D-galactose, $(+)$-D-glucose and L-tyrosine are not utilized. In the API ZYM system, alkaline phosphatase, esterase, esterase lipase, lipase, leucine arylamidase, valine arylamidase, cystine arylamidase, trypsin, $\alpha$-chymotrypsin, acid phosphatase and naphthol-AS-BI-phosphohydrolase are present, but all of the enzymes relating to the metabolism of carbohydrates are absent.

The type strain, A37.1 $1^{\mathrm{T}}\left(=\right.$ NCIMB $14147^{\mathrm{T}}=$ DSM $\left.18841^{\mathrm{T}}\right)$, was isolated from seawater from a holding tank for turbot (Psetta maxima), in Galicia in north-west Spain.

\section{Acknowledgements}

This investigation was supported by grant PGIDIT 04 RMA 003E from the Xunta de Galicia, Spain. The authors acknowledge Stolt Sea Farm for collaboration during this study, Dr J. P. Euzéby (Laboratoire de Bactériologie, École Nationale Vétérinaire, Toulouse, France) for his help with species names, and the referees for constructive suggestions.

\section{References}

Bernardet, J.-F., Segers, P., Vancanneyt, M., Berthe, F., Kersters, K. \& Vandamme, P. (1996). Cutting a Gordian knot: emended classification and description of the genus Flavobacterium, emended description of the family Flavobacteriaceae, and proposal of Flavobacterium hydatis nom. nov. (basonym, Cytophaga aquatilis Strohl and Tait 1978). Int J Syst Bacteriol 46, 128-148.

Bernardet, J.-F., Nakagawa, Y. \& Holmes, B. (2002). Proposed minimal standards for describing new taxa of the family Flavobacteriaceae and emended description of the family. Int J Syst Evol Microbiol 52, 1049-1070.

Buck, J. D. (1982). Non-staining (KOH) method for determination of gram reactions of marine bacteria. Appl Environ Microbiol 44, 992-993. 
Cashion, P., Holder-Franklin, M. A., McCully, J. \& Franklin, M. (1977). A rapid method for base ratio determination of bacterial DNA. Anal Biochem 81, 461-466.

Choi, D. H., Kim, Y.-G., Hwang, C. Y., Yi, H., Chun, J. \& Cho, B. C. (2006). Tenacibaculum litoreum sp. nov, isolated from tidal flat sediment. Int J Syst Evol Microbiol 56, 635-640.

Cowan, S. T. \& Steel, K. J. (1965). Manual for the Identification of Medical Bacteria. London: Cambridge University Press.

De Ley, J., Cattoir, H. \& Reynaerts, A. (1970). The quantitative measurement of DNA hybridization from renaturation rates. Eur $J$ Biochem 12, 133-142.

Fitch, W. M. (1971). Toward defining the course of evolution: minimum change for a specific tree topology. Syst Zool 20, 406-416.

Frette, L., Jørgensen, N. O. G., Irming, H. \& Kroer, N. (2004). Tenacibaculum skagerrakense sp. nov., a marine bacterium isolated from the pelagic zone in Skagerrak, Denmark. Int J Syst Evol Microbiol 54, 519-524.

Hansen, G. H., Bergh, O., Michaelsen, J. \& Knappskog, D. (1992). Flexibacter ovolyticus sp. nov. a pathogen of eggs and larvae of Atlantic halibut, Hippoglossus hippoglossus L. Int J Syst Bacteriol 42, 451-458.

Huß, V. A. R., Festl, H. \& Schleifer, K. H. (1983). Studies on the spectrophotometric determination of DNA hybridization from renaturation rates. Syst Appl Microbiol 4, 184-192.

Jung, S.-Y., Oh, T.-K. \& Yoon, J.-H. (2006). Tenacibaculum aestuarii sp. nov. isolated from a tidal flat sediment in Korea. Int J Syst Evol Microbiol 56, 1577-1581.

Kimura, M. (1980). A simple model for estimating evolutionary rates of base substitutions through comparative studies of nucleotide sequences. J Mol Evol 16, 111-120.

Kumar, S., Tamura, K. \& Nei, M. (2004). MEGA3: integrated software for molecular evolutionary genetics analysis and sequence alignment. Brief Bioinform 5, 150-163.

Pazos, F., Santos, Y., Macias, A. R., Núñez, S. \& Toranzo, A. E. (1996). Evaluation of media for the successful culture of Flexibacter maritimus. J Fish Dis 19, 193-197.

Piñeiro-Vidal, M., Centeno-Sestelo, G., Riaza, A. \& Santos, Y. (2007). Isolation of pathogenic Tenacibaculum maritimum-related organisms from diseased turbot and sole cultured in the Northwest of Spain. Bull Eur Assoc Fish Pathol 27, 29-35.

Reichenbach, H. (1989). The order Cytophagales Leadbetter 1974, $99^{\mathrm{AL}}$. In Bergey's Manual of Systematic Bacteriology, vol. 3, pp. 20112073. Edited by J. T. Staley, M. P. Bryant, N. Pfennig \& J. C. Holt. Baltimore: Williams \& Wilkins.

Reichenbach, H. (1992a). The order Cytophagales. In The Prokaryotes, 2nd edn, vol. 4, pp. 3631-3675. Edited by A. Balows, H. G. Trüper, M. Dworkin, W. Harder \& K. H. Schleifer. New York: Springer.

Reichenbach, H. (1992b). Flavobacteriaceae fam. nov. In Validation of the Publication of the New Names and New Combinations Previously Effectively Published Outside the IJSB, List no. 41. Int J Syst Bacteriol 42, 327-329.

Saitou, N. \& Nei, M. (1987). The neighbor-joining method: a new method for reconstructing phylogenetic trees. Mol Biol Evol 4, 406-425.

Sheu, S.-Y., Lin, K.-Y., Chou, J.-H., Chang, P.-S., Arun, A. B., Young, C.-C. \& Chen, W.-M. (2007). Tenacibaculum litopenaei sp. nov., isolated from a shrimp mariculture pond. Int J Syst Evol Microbiol 57, 1148-1153.

Suzuki, M., Nakagawa, Y., Harayama, S. \& Yamamoto, S. (2001). Phylogenetic analysis and taxonomic study of marine Cytophaga-like bacteria: proposal for Tenacibaculum gen. nov. with Tenacibaculum maritimum comb. nov. and Tenacibaculum ovolyticum comb. nov., and description of Tenacibaculum mesophilum sp. nov. and Tenacibaculum amylolyticum sp. nov. Int J Syst Evol Microbiol 51, 1639-1652.

Thompson, J. D., Higgins, D. G. \& Gibson, T. J. (1994). CLUSTAL W: improving the sensitivity of progressive multiple sequence alignment through sequence weighting, position-specific gap penalties and weight matrix choice. Nucleic Acids Res 22, 4673-4680.

Wakabayashi, H., Hikida, M. \& Masumura, K. (1986). Flexibacter maritimus sp. nov., a pathogen of marine fishes. Int J Syst Bacteriol 36, 396-398.

Yoon, J.-H., Kang, S.-J. \& Oh, T.-K. (2005). Tenacibaculum lutimaris sp. nov., isolated from a tidal flat in the Yellow Sea, Korea. Int J Syst Evol Microbiol 55, 793-798. 